\title{
Dissolved inorganic carbon dynamics in the waters surrounding forested mangroves of the Ca Mau Province (Vietnam)
}

\author{
Y.J.-M. Koné, A.V. Borges* \\ Unité d'Océanographie Chimique, Institut de Physique (B5), Université de Liège, MARE, B-4000 Sart-Tilman, Belgium
}

Received 19 February 2007; accepted 3 October 2007

Available online 29 October 2007

\begin{abstract}
Dissolved inorganic carbon (DIC) and ancillary data were obtained during the dry and rainy seasons in the waters surrounding two 10-yearold forested mangrove sites (Tam Giang and Kiên Vàng) located in the Ca Mau Province (South-West Vietnam). During both seasons, the spatial variations of partial pressure of $\mathrm{CO}_{2}\left(\mathrm{pCO}_{2}\right)$ were marked, with values ranging from $704 \mathrm{ppm}$ to $11481 \mathrm{ppm}$ during the dry season, and from $1209 \mathrm{ppm}$ to $8136 \mathrm{ppm}$ during the rainy season. During both seasons, DIC, $\mathrm{pCO}_{2}$, total alkalinity (TAlk) and oxygen saturation levels $\left(\% \mathrm{O}_{2}\right)$ were correlated with salinity in the mangrove creeks suggesting that a combination of lower water volume and longer residence time (leading to an increase in salinity due to evaporation) enhanced the enrichment in DIC, $\mathrm{pCO}_{2}$ and TAlk, and an impoverishment in $\mathrm{O}_{2}$. The low $\mathrm{O}_{2}$ and high DIC and $\mathrm{pCO}_{2}$ values suggest that heterotrophic processes in the water column and sediments controlled these variables. The latter processes were meaningful since the high DIC and TAlk values in the creek waters were related to some extent to the influx of pore waters, consistent with previous observations. This was confirmed by the stochiometric relationship between TAlk and DIC that shows that anaerobic processes control these variables, although this approach did not allow identifying unambiguously the dominant diagenetic carbon degradation pathway. During the rainy season, dilution led to significant decreases of salinity, TAlk and DIC in both mangrove creeks and adjacent main channels. In the Kiên Vàng mangrove creeks a distinct increase of $\mathrm{pCO}_{2}$ and decrease of $\% \mathrm{O}_{2}$ were observed. The increase of TSM suggested enhanced inputs of organic matter probably from land surrounding the mangrove creeks, that could have led to higher benthic and water column heterotrophy. However, the flushing of water enriched in dissolved $\mathrm{CO}_{2}$ originating from soil respiration and impoverished in $\mathrm{O}_{2}$ could also have explained to some extent the patterns observed during the rainy season. Seasonal variations of $\mathrm{pCO}_{2}$ were more pronounced in the Kiên Vàng mangrove creeks than in the Tam Giang mangrove creeks. The air-water $\mathrm{CO}_{2}$ fluxes were 5 times higher during the rainy season than during the dry season in the Kiên Vàng mangrove creeks. In the Tam Giang mangrove creeks, the air-water $\mathrm{CO}_{2}$ fluxes were similar during both seasons. The air-water $\mathrm{CO}_{2}$ fluxes ranged from $27.1 \mathrm{mmol} \mathrm{C} \mathrm{m}^{-2} \mathrm{~d}^{-1}$ to $141.5 \mathrm{mmol} \mathrm{C} \mathrm{m}^{-2} \mathrm{~d}^{-1}$ during the dry season, and from $81.3 \mathrm{mmol} \mathrm{m}^{-2} \mathrm{~d}^{-1}$ to $154.7 \mathrm{mmol} \mathrm{m} \mathrm{m}^{-1}$ during the rainy season. These values are within the range of values previously reported in other mangrove creeks and confirm that the emission of $\mathrm{CO}_{2}$ from waters surrounding mangrove forests are meaningful for the carbon budgets of mangrove forests.
\end{abstract}

(C) 2007 Elsevier Ltd. All rights reserved.

Keywords: coastal ocean; mangroves; carbon dioxide; dissolved inorganic carbon; total alkalinity

\section{Introduction}

The exchange of carbon dioxide $\left(\mathrm{CO}_{2}\right)$ between coastal waters and the atmosphere could lead to a major revision of budgets of $\mathrm{CO}_{2}$ fluxes at regional (Frankignoulle and Borges, 2001a; Borges et al., 2006) or global scales (Tsunogai et al.,

\footnotetext{
* Corresponding author.

E-mail address: alberto.borges@ulg.ac.be (A.V. Borges).
}

1999; Thomas et al., 2004; Borges, 2005; Borges et al., 2005). Marginal seas have been estimated to act on the whole as a sink for atmospheric $\mathrm{CO}_{2}$ ranging from $-0.4 \mathrm{PgC} \mathrm{yr}^{-1}$ to $-1.0{\mathrm{PgC} \mathrm{yr}^{-1}}^{-1}$ (Tsunogai et al., 1999; Thomas et al., 2004; Borges, 2005; Borges et al., 2005) that would lead to a major revaluation of the oceanic sink for atmospheric $\mathrm{CO}_{2}$, since open oceanic waters are a $\mathrm{CO}_{2}$ sink of about $-1.6 \mathrm{PgC} \mathrm{yr}^{-1}$ (Takahashi et al., 2002). Near-shore coastal systems (estuaries, saltmarsh waters, mangrove waters, coral reefs, and coastal 
upwelling systems) act as sources of $\mathrm{CO}_{2}$ and a preliminary upward scaling suggests that the overall emission of $\mathrm{CO}_{2}$ from these systems could be as high as $+0.4 \mathrm{PgC} \mathrm{yr}^{-1}$, thus balancing the $\mathrm{CO}_{2}$ sink associated to marginal seas (Borges, 2005; Borges et al., 2005). However, the air-water fluxes of $\mathrm{CO}_{2}$ from coastal environments are highly uncertain and in large part this reflects data coverage that is spatially biased towards the temperate latitudes of the Northern Hemisphere (Borges, 2005; Borges et al., 2005). Importantly, there is a scarcity of air-water $\mathrm{CO}_{2}$ flux data in coastal environments at subtropical and tropical latitudes that receive about $60 \%$ of the global freshwater discharge and an equivalent fraction of riverine organic carbon inputs (e.g. Ludwig et al., 1996). Coastal environments at these latitudes are then highly dynamic in terms of carbon cycling and are expected to be characterised by considerable exchanges of $\mathrm{CO}_{2}$ with the atmosphere.

Mangrove forests are intertidal habitats that occupy a major part of the tropical and sub-tropical coastlines but their surface area has been largely reduced in the past decades due to human activities. The most recent estimates show a decrease in surface area from $198 \times 10^{3} \mathrm{~km}^{2}$ in 1980 to $146 \times 10^{3} \mathrm{~km}^{2}$ in 2000 (FAO, 2003). High population pressure in coastal areas has led to the conversion of many mangrove areas to other uses, including infrastructure, aquaculture, rice growing and salt production. In South-East Asia, mangrove clearance has mainly been driven by the development of shrimp aquaculture. Vietnam has reportedly lost more than $80 \%$ of its mangrove forests over the last 50 years, and shrimp aquaculture is thought to be the single largest threat to those that remain (Thornton et al., 2003). Mangrove forests are characterised by high above-ground primary production, efficient nutrient recycling and a permanent exchange with terrestrial and marine ecosystems. The low ratio of sediment respiration to canopy primary production makes mangroves highly efficient in the sequestration of carbon into above and below ground plant biomass (e.g. Jennerjahn and Ittekkot, 2002). Carbon burial is in the order of $23{\mathrm{TgC} \mathrm{yr}^{-1}}^{-1}$, which makes up about $15 \%$ of the organic carbon accumulating in modern marine sediments (Jennerjahn and Ittekkot, 2002; Duarte et al., 2005). The organic carbon supplied to mangrove sediments and creek waters has several sources, either local (mangrove detritus, and microphytobenthos) or allochthonous (phytoplankton, seagrass-derived material, and terrestrial non-mangrove), but the relative contribution of these sources varies considerably from one site to another (Bouillon et al., 2004; Bouillon and Boschker, 2006). Due to this organic carbon supply, the aquatic compartment and the sediments of mangroves are largely net heterotrophic (e.g. Gattuso et al., 1998), and as a consequence, the aquatic compartment associated to mangrove forests acts as a source of $\mathrm{CO}_{2}$ to the atmosphere (Borges et al., 2003; Bouillon et al., 2003, 2007a,b,c), although the range of the $\mathrm{CO}_{2}$ fluxes reported so far encompasses one order of magnitude. The sediments of human impacted mangroves are known to be more acid than natural ones (Middelburg et al., 1996), while the dominant diagenetic organic carbon degradation pathway of recently reclaimed mangroves is different than in natural (old) ones (Alongi et al., 1998). The impact of these processes on dissolved inorganic carbon (DIC) dynamics of the adjacent waters and related air-water $\mathrm{CO}_{2}$ fluxes has not yet been investigated.

We reported DIC and ancillary data obtained during the dry and rainy seasons in the waters surrounding two 10-year-old forested mangrove sites (Tam Giang and Kiên Vàng) located in the Nam Can and Ngoc Hien Districts (Ca Mau Province, South-West Vietnam, Fig. 1). We aim to describe spatial and temporal distributions and inter-site variability of DIC and ancillary data in mangrove creeks and compare the range of values of these forested mangroves to the non-forested systems studied so far.

\section{Materials and methods}

\subsection{Study area}

The Ca Mau Province is characterised by a strong bimodal rainfall pattern, with a clearly defined rainy season extending from May to November, and very little rainfall during the rest of the year, and an annual average rainfall of about $2400 \mathrm{~mm}$ (Clough et al., 2002). Approximately 46 species of mangrove trees have been identified in the region and the forested species are mainly in the families of Rhizophoraceae (10 species), Sonneratiaceae (3 species) and Verbennaceae (4 species) (Binh et al., 1997). The tidal amplitude ranges between $0.5 \mathrm{~m}$ and $0.8 \mathrm{~m}$, and the water in the mangrove creeks is either brackish (salinities of 24-26 during the rainy season) or saline (salinities of 30-32 during the dry season), and there is no distinct terrestrial source of freshwater in the area (Binh et al., 1997).

Prior to the Vietnam-American war, Ca Mau Province was covered extensively by mangrove forests, most of which were destroyed by defoliants during the war leading to the destruction of $80 \%$ of the of mature Rhizophora forests (Clough et al., 2002). Following the Vietnam reunification in 1975 , natural regeneration and extensive replanting, mainly with monocultures of Rhizophora apiculata, led to the partial recovery of mangrove vegetation. Recent and rapid expansion of shrimp aquaculture has contributed to the loss of more than half the mangrove forest that existed in Ca Mau and Bac Lieu provinces in 1982. Under the current forest management policy, Rhizophora apiculata is planted at an initial density of $20,000 \mathrm{ha}^{-1}$, with thinnings by $20-30 \%$ at 5,10 and 15 years, and the final harvest at 20 years (Clough et al., 2002).

\subsection{Sampling and analytical techniques}

Two sampling cruises were carried out on 10-14 April, 2004 (dry season) and 23-25 October, 2005 (rainy season) in two mangrove forests (Tam Giang and Kiên Vàng). The sampling strategy was aimed: (1) to describe the seasonal variability of DIC and related parameters within each of the two mangrove forests, (2) to assess the spatial variability within each of the two mangrove forests with a more or less regular grid, and (3) to compare the temporal and spatial variability between the two mangrove forests. Sampling was carried in the main (wider) channels adjacent to the mangrove forests 

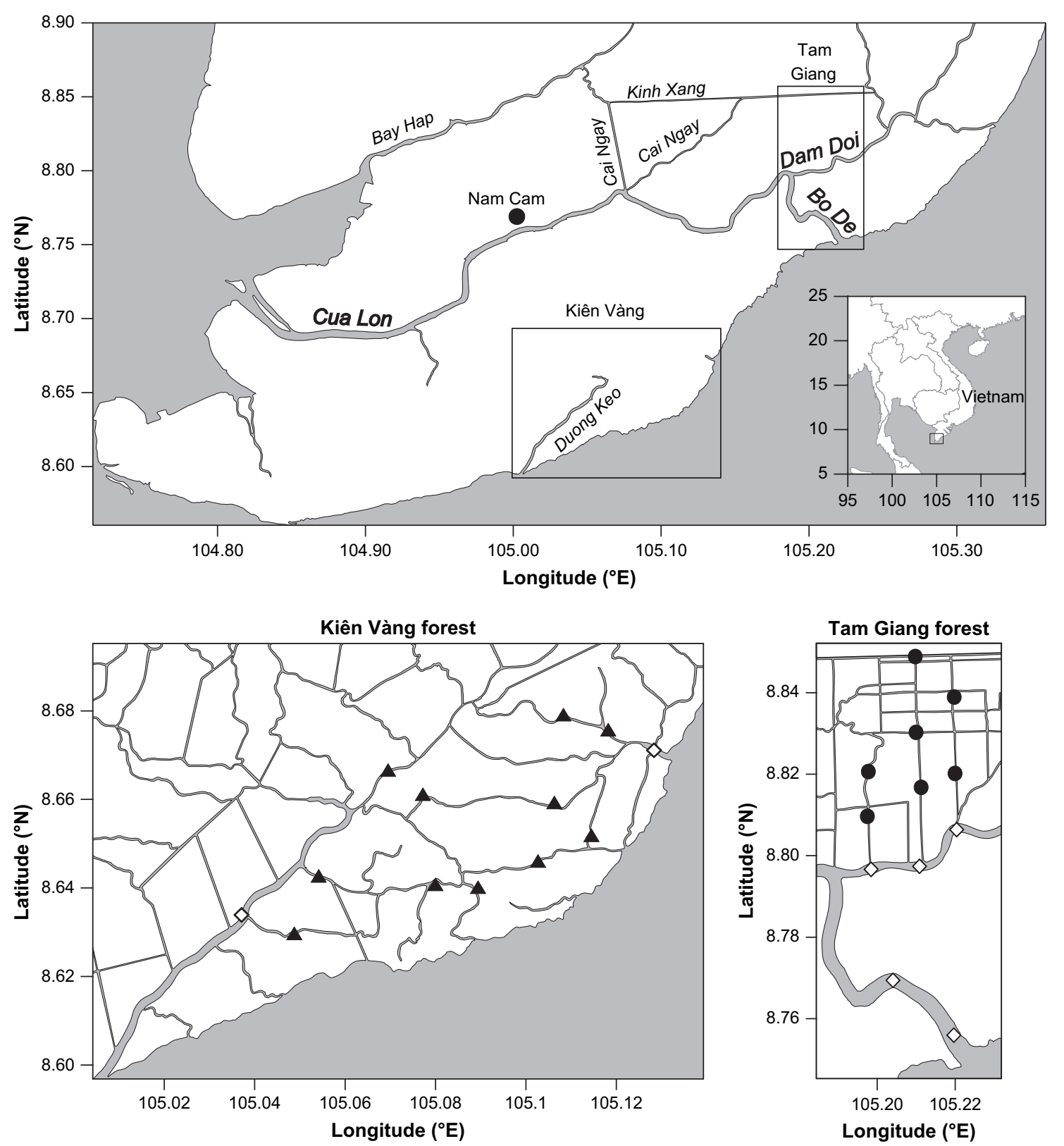

Fig. 1. Location of the sampling stations in Tam Giang (solid circles) and Kiên Vàng (solid triangles) mangrove creeks and in adjacent main channels (open diamonds).

(hereafter "adjacent main channels") and a range of mangrove creeks of different width and of variable distance from the adjacent main channels. Due to logistic constrains, the various stations were sampled (only once) at different tidal stages.

Subsurface waters (top $30 \mathrm{~cm}$ ) were sampled with a $1.7-\mathrm{L}$ Niskin bottle, and oxygen and $\mathrm{pH}$ measurements were carried out immediately after collection. Salinity and water temperature were measured in-situ using a portable thermosalinometer (WTW Cond-340) with a precision of \pm 0.1 and $\pm 0.1^{\circ} \mathrm{C}$, respectively. The oxygen saturation level $\left(\% \mathrm{O}_{2}\right)$ was measured with a polarographic electrode (WTW Oxi-340) calibrated on saturated air, with an accuracy of $\pm 0.1 \%$. $\mathrm{pH}$ was measured with a combination electrode (Metrohm 6.0232.100) calibrated on the U.S. National Bureau of Standards scale as described by Frankignoulle and Borges (2001b), with a precision and estimated accuracy of respectively \pm 0.001 and $\pm 0.005 \mathrm{pH}$ units. A volume of about of $100 \mathrm{ml}$ was filtered through $0.2-\mu \mathrm{m}$ pore size polysulphone filters, and was stored at ambient temperature in polyethylene bottles for the determination of total alkalinity (TAlk), within 1 week after sampling. TAlk was measured on 50-ml samples by automated Gran electro-titration with $0.1 \mathrm{M} \mathrm{HCl}$ as titrant, with a reproducibility of $\pm 1 \mu \mathrm{mol} \mathrm{kg}{ }^{-1}$. Measurements TAlk and $\mathrm{pH}$ were used to compute the partial pressure of $\mathrm{CO}_{2}\left(\mathrm{pCO}_{2}\right)$ and DIC, with an estimated accuracy of $\pm 4 \mathrm{ppm}$ and $\pm 4 \mu \mathrm{mol} \mathrm{kg}{ }^{-1}$, respectively (for details refer to Frankignoulle and Borges, 2001b). Total suspended matter (TSM) measurements were obtained by filtering a known volume of water on pre-weighted glass-fibre 
filters (Whatman GF/F). Wind speed was measured at each sampling station with a hand-held anemometer. Air-water fluxes of $\mathrm{CO}_{2}$ were calculated according to:

$F=\alpha \cdot k \cdot \Delta \mathrm{pCO}_{2}$

where $\alpha$ is the solubility coefficient of $\mathrm{CO}_{2}, k$ is the gas transfer velocity of $\mathrm{CO}_{2}$ and $\Delta \mathrm{pCO}_{2}$ is the air-water gradient of $\mathrm{pCO}_{2}$. We computed $k$ using the wind speed field measurements, and the parameterisation as a function of wind speed given by Carini et al. (1996), that is assumed suitable under the considered environmental conditions (Borges et al., 2003).

The difference of the means of populations of variables (between sampling sites for one given season or between seasons for one given sampling site) were statistically analysed with a two-tailed unpaired Student $t$-test. The normality of distribution of the populations was tested with the KolmogorovSmirnov test, and all tested populations were found to be normally distributed. $P$ values are not explicitly mentioned hereafter but "significant(ly)" refers to $P<0.05$, "very significant(ly)" refers to $P<0.01$, "highly significant(ly)" refers to $P<0.001$, and "not significant(ly)" refers to $P>0.05$ at the 0.05 level. Statistical analyses were carried out with Prism 4.00 (GraphPad).

\section{Results and discussion}

\subsection{Spatial and seasonal variations of DIC and ancillary data}

The spatial and temporal distributions of salinity, $\% \mathrm{O}_{2}$, DIC, $\mathrm{pCO}_{2}$, TAlk, and TSM in the surface waters of the mangrove creeks of the Tam Giang and Kiên Vàng forests and of the adjacent main channels are shown on Figs. 2-5, and average values for each site are reported in Table 1. In the Tam Giang mangrove creeks, salinity showed highly significant seasonal variations, and average values decreased from 33.1 during the dry season to 13.3 during the rainy season (Table 1). In the Kiên Vàng mangrove creeks and adjacent main channels a highly significant decrease of average salinity from the dry to rainy season was also observed. In the two mangrove creeks, during both seasons, the salinity spatial variations were of the same order of magnitude, of about 1 (Figs. 2-5). During the rainy season, the average salinity was significantly higher in the Kiên Vàng mangrove creeks than in the Tam Giang mangrove creeks, but average salinity was not significantly different in the two mangrove creeks during the dry season. Average salinity in the adjacent main channels was not significantly different than in the Tam Giang mangrove creeks during both seasons. In the adjacent main channels, average salinity was significantly to very significantly lower than in the Kiên Vàng mangrove creeks, during the rainy and dry season, respectively. This is due to higher effect of evaporation in the mangrove creeks that have a smaller water volume (narrower and shallower than the adjacent main channels) and probably a longer water residence time, particularly during the dry season.
Surface waters in the mangrove creeks and adjacent main channels were supersaturated with respect to atmospheric $\mathrm{CO}_{2}$ during both seasons (Tables 1 and 2). The adjacent main channels were characterised by significantly to very significantly lower average $\mathrm{pCO}_{2}$ compared to the two mangrove creeks during the dry and rainy season, respectively. In the Tam Giang mangrove creeks, average $\mathrm{pCO}_{2}$ was not significantly different during both seasons, but $\mathrm{pCO}_{2}$ values showed less spatial variability during the rainy season (Figs. 4 and 5). In the Kiên Vàng mangroves creeks, a significant twofold increase of average $\mathrm{pCO}_{2}$ was observed from the dry to the rainy season, while spatial variability remained similar (Figs. 2 and 3 ). In the adjacent main channels, average $\mathrm{pCO}_{2}$ showed a highly significant two fold increase from the dry season to the rainy season.

During both seasons, and in the two mangrove creeks, spatial variations of TAlk and DIC were apparent and similar in amplitude (Figs. 2-5). During both seasons, average TAlk and DIC values were significantly to highly significantly higher in the mangrove creeks than in the adjacent main channels. A highly significant decrease of average TAlk values during the rainy season compared to the dry season was observed in both mangrove creeks and in the main adjacent channels. The decrease of DIC from the dry to the rainy season was highly significant in the main adjacent channels and significant in both mangrove creeks. The decrease of TAlk and DIC is related to dilution.

The mangrove creeks and the adjacent main channels were characterised by low $\% \mathrm{O}_{2}$ values during both seasons (Table 1), with significantly to highly significantly lower average values in the creek waters compared to the adjacent main channels. In the mangrove creeks and the adjacent main channels, $\% \mathrm{O}_{2}$ values decreased by about $10 \%$ of level of saturation during the rainy compared to the dry season.

Average TSM values were significantly to very significantly higher in the Kiên Vàng mangrove creeks than in the Tam Giang mangrove creeks during the dry and rainy seasons, respectively. During both seasons, average TSM was significantly higher in the Kiên Vàng mangrove creeks than in the adjacent main channels. During the rainy season, average TSM was significantly lower in Tam Giang mangrove creeks than in the adjacent main channels, but was not significantly different during the dry season. Average TSM was very significantly higher in the Kiên Vàng mangrove creeks during the rainy season compared to the dry season. Average TSM was not significantly different in the Tam Giang mangrove creeks during the rainy season compared to the dry season.

The variation of $\mathrm{pCO}_{2}$, DIC, TAlk, $\% \mathrm{O}_{2}$ and TSM as a function of salinity, during the dry and rainy season are shown on Figs. 6 and 7, respectively. During both seasons, an increase in $\mathrm{pCO}_{2}$, DIC and TAlk and a decrease of $\% \mathrm{O}_{2}$ were observed in the mangroves creeks along the salinity gradient. TSM values were scattered but roughly showed an increasing trend with salinity. These trends were more pronounced in the Tam Giang mangrove creeks than in Kiên Vàng mangrove creeks, during the dry season, and similar in amplitude in both mangrove creeks during the rainy season. During both seasons, $\mathrm{pCO}_{2}$ 

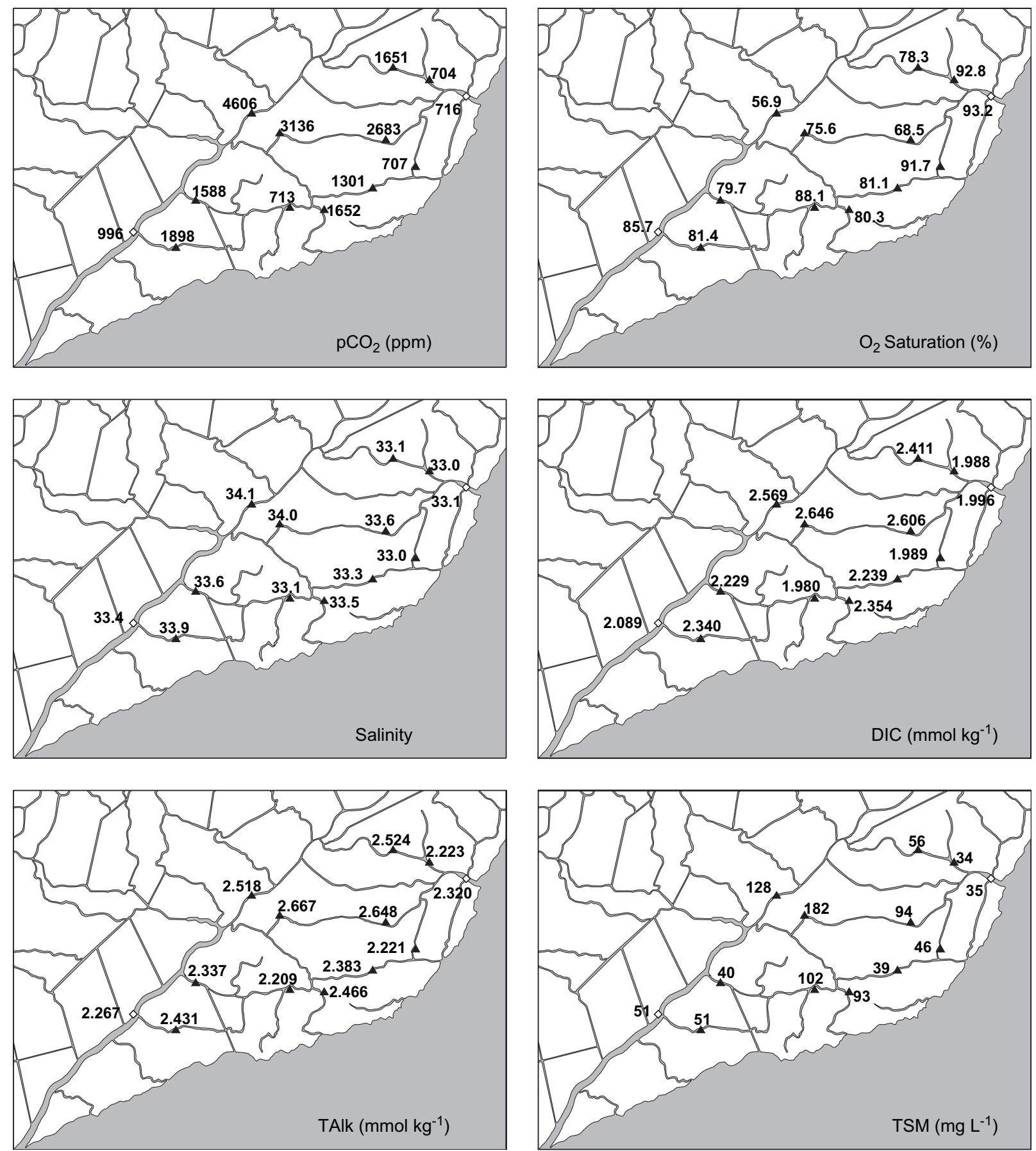

Fig. 2. Spatial distribution of $\mathrm{pCO}_{2}(\mathrm{ppm}), \% \mathrm{O}_{2}(\%)$, salinity, TAlk $\left(\mathrm{mmol} \mathrm{kg}^{-1}\right)$, DIC $\left(\mathrm{mmol} \mathrm{kg}^{-1}\right)$ and TSM $\left(\mathrm{mg} \mathrm{L}^{-1}\right)$ in the Kiên Vàng mangrove creeks (solid triangles), and adjacent main channels (open diamonds) during the dry season.

and $\% \mathrm{O}_{2}$ were well correlated suggesting that these variables were controlled by biological process; values of $\mathrm{pCO}_{2}$ above atmospheric equilibrium (365 ppm) coinciding with $\% \mathrm{O}_{2}$ values below saturation imply that heterotrophic processes were dominant.

Higher values of $\mathrm{pCO}_{2}$, DIC and TAlk in the mangrove creeks than in the adjacent aquatic systems are consistent with previous observations by Borges et al. (2003) in Papua New Guinea and the Bahamas, by Bouillon et al. (2003) in the Gautamani Godavari delta (India), by Bouillon et al. (2007a) in the Tana estuary (Kenya), by Bouillon et al. (2007b) in the Ras Dege mangrove creek (Tanzania), and by Bouillon et al. (2007c) in Gazi bay (Kenya). This can be related to several mechanisms: (a) mangrove tidal creeks are characterised by a long residence time of the water mass that favours a local degradation of organic matter provided by the canopy and/or allochthonous sources, and also promotes a stronger increase of salinity in the mangrove creeks compared to the adjacent water masses due to evaporation; and (b) the influx of pore water which mixes with the creek water 

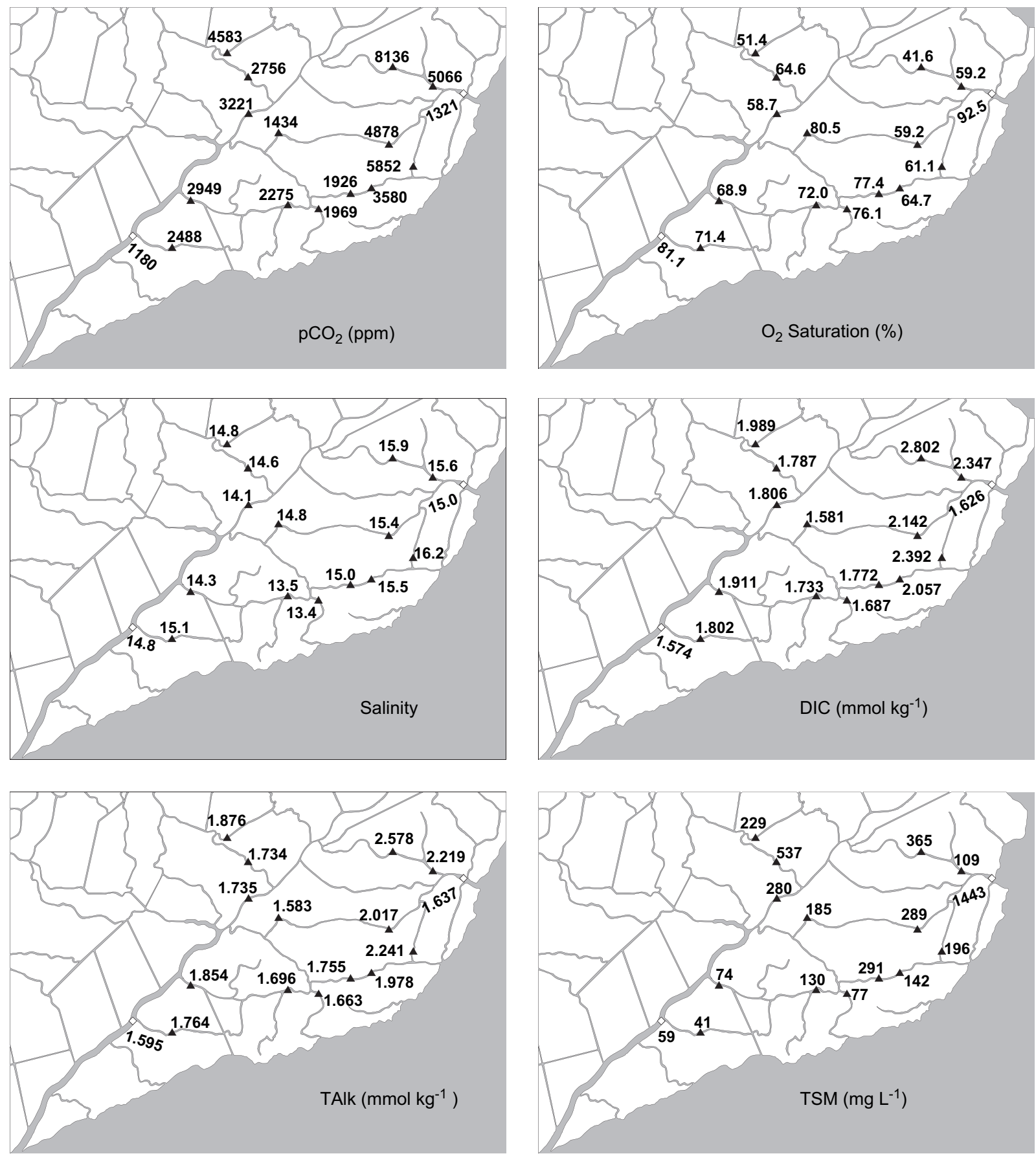

Fig. 3. Spatial distribution of $\mathrm{pCO}_{2}(\mathrm{ppm}), \% \mathrm{O}_{2}(\%)$, salinity, TAlk $\left(\mathrm{mmol} \mathrm{kg}^{-1}\right)$, DIC $\left(\mathrm{mmol} \mathrm{kg}^{-1}\right)$ and TSM $\left(\mathrm{mg} \mathrm{L}^{-1}\right)$ in the Kiên Vàng mangrove creeks (solid triangles), and adjacent main channels (open diamonds) during the rainy season.

substantially affects the chemical properties of the latter-this will also be enhanced in the creeks by a smaller water volume and by a longer residence time of the water mass.

Seasonal variations of remineralisation rates of mangrove canopy derived organic matter are expected to be minor due to the limited seasonal changes in temperature and in litter fall rates (Holmer et al., 2001; Kristensen et al., 2000). Alongi et al. (2001) showed that benthic respiration in mangrove ecosystems was more dependent upon allochthonous organic matter inputs rather than aboveground primary production, in agreement with benthic bacteria isotopic signatures (Bouillon et al., 2004; Bouillon and Boschker, 2006). This is also in agreement with recent findings by Bouillon et al. (2007a) in the mangrove dominated Tana estuary in Kenya that showed that water column particulate and dissolved organic matter were dominated by inputs from the non-mangrove drainage basin rather than from mangrove derived material. The increase of $\mathrm{pCO}_{2}$ and decrease of $\% \mathrm{O}_{2}$ in the mangrove creeks during the rainy season suggests an increase of heterotrophic activity in sediments and/or the water column, as also reported 

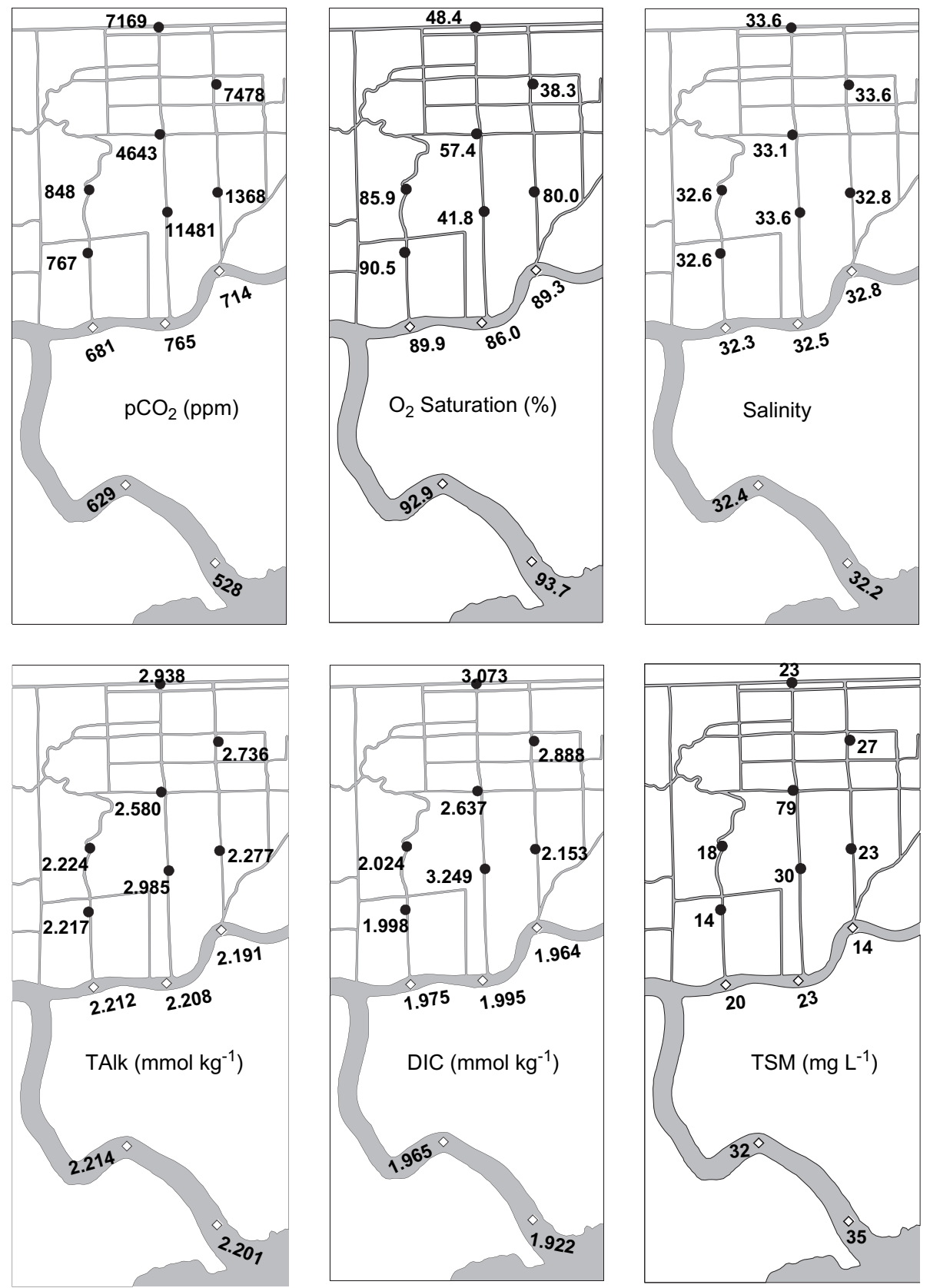

Fig. 4. Spatial distribution of $\mathrm{pCO}_{2}(\mathrm{ppm}), \% \mathrm{O}_{2}(\%)$, salinity, TAlk $\left(\mathrm{mmol} \mathrm{kg}^{-1}\right)$, DIC $\left(\mathrm{mmol} \mathrm{kg}^{-1}\right)$ and TSM $\left(\mathrm{mg} \mathrm{L}^{-1}\right)$ in the Tam Giang mangrove creeks (solid circles), and main adjacent channel (open diamonds) during the dry season.

in the Sundarban mangroves by Biswas et al. (2004). The increase of TSM also suggests an increase of soil flushing during the rainy season, probably from the land surrounding the mangrove forests. Such an additional input of non-mangrove organic matter is expected to fuel additional benthic and water column heterotrophy. Another process that could explain the higher $\mathrm{pCO}_{2}$ and lower $\% \mathrm{O}_{2}$ values during the rainy season is the increased input of mangrove porewaters, or from groundwater water enriched in $\mathrm{CO}_{2}$ and impoverished in $\mathrm{O}_{2}$ after flushing the soils from adjacent non-mangrove land. The influence of the input of mangrove porewaters on the $\mathrm{CO}_{2}$ and $\mathrm{O}_{2}$ dynamics in mangrove creeks has been documented (Ovalle et al., 1990; Borges et al., 2003; Bouillon et al., 2007b) and could be increased due to flushing by rain (Barnes et al., 2006), in analogy with freshwater systems where the flux of dissolved $\mathrm{CO}_{2}$ originating from soil respiration is known to strongly contribute to the emission of $\mathrm{CO}_{2}$ to the atmosphere (Kling et al., 1991; Jones and Mulholland, 1998; Cole and Caraco, 2001; Jones et al., 2003; Duarte and Prairie, 2005). The present data-set does not allow discrimination of these different causes of higher $\mathrm{pCO}_{2}$ values during the rainy season that probably co-occur.

Diagenetic organic carbon degradation in mangroves has several anaerobic pathways (denitrification, manganese reduction, iron reduction, sulphate reduction and methanogenesis) that increase pore water TAlk (except methanogenesis). 

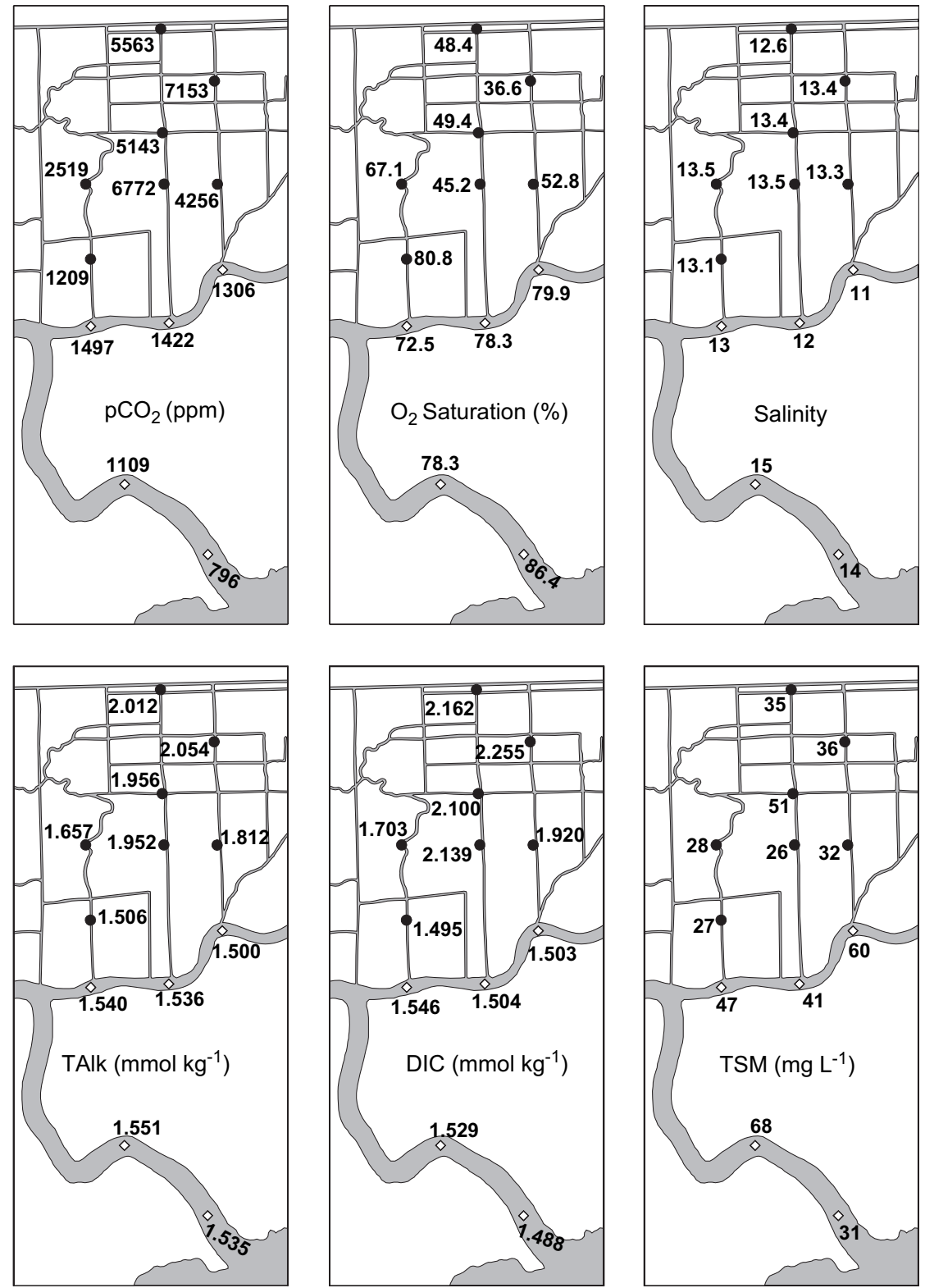

Fig. 5. Spatial distribution of $\mathrm{pCO}_{2}(\mathrm{ppm}), \% \mathrm{O}_{2}(\%)$, salinity, TAlk $\left(\mathrm{mmol} \mathrm{kg}^{-1}\right)$, DIC $\left(\mathrm{mmol} \mathrm{kg}^{-1}\right)$ and TSM $\left(\mathrm{mg} \mathrm{L}^{-1}\right)$ in the Tam Giang mangrove creeks (solid circles), and adjacent main channels (open diamonds) during the rainy season.

Generally, sulphate reduction and aerobic respiration are the main pathways of organic matter degradation in mangrove sediments (Alongi et al., 2001). For instance, aerobic respiration accounted for $63-94 \%$ of total benthic organic carbon decomposition in Rhizophora apiculata plantations of the Mekong delta (Alongi et al., 2000a), while sulphate reduction represented $74 \%$ of benthic organic carbon decomposition in Western Australia mangroves (Alongi, 1998). According to

Table 1

Average \pm standard deviation of salinity, $\mathrm{pCO}_{2}$, TAlk, DIC, $\% \mathrm{O}_{2}$ and TSM in the Kiên Vàng and Tam Giang mangroves creeks and adjacent main channels, during the dry and rainy seasons

\begin{tabular}{|c|c|c|c|c|c|c|c|}
\hline Sites & Season & Salinity & $\begin{array}{l}\mathrm{pCO}_{2} \\
(\mathrm{ppm})\end{array}$ & $\begin{array}{l}\text { TAlk } \\
\left(\mathrm{mmol} \mathrm{kg}^{-1}\right)\end{array}$ & $\begin{array}{l}\text { DIC } \\
\left(\mathrm{mmol} \mathrm{kg}^{-1}\right)\end{array}$ & $\begin{array}{l}\% \mathrm{O}_{2} \\
(\%)\end{array}$ & $\begin{array}{l}\text { TSM } \\
\left(\mathrm{mg} \mathrm{L}^{-1}\right)\end{array}$ \\
\hline \multirow[t]{2}{*}{ Kiên Vàng } & Dry & $33.5 \pm 0.4$ & $1876 \pm 1196$ & $2.421 \pm 0.163$ & $2.305 \pm 0.246$ & $79.5 \pm 10.3$ & $79 \pm 46$ \\
\hline & Rainy & $14.9 \pm 0.8$ & $3651 \pm 1856$ & $1.907 \pm 0.276$ & $1.986 \pm 0.336$ & $64.8 \pm 10.7$ & $210 \pm 134$ \\
\hline & Rainy & $13.3 \pm 0.3$ & $4698 \pm 2187$ & $1.850 \pm 0.203$ & $1.969 \pm 0.278$ & $54.3 \pm 14.8$ & $34 \pm 9$ \\
\hline \multirow[t]{2}{*}{ Adjacent main channels } & Dry & $32.7 \pm 0.4$ & $718 \pm 144$ & $2.217 \pm 0.025$ & $1.987 \pm 0.051$ & $90.1 \pm 3.3$ & $29 \pm 15$ \\
\hline & Rainy & $13.5 \pm 1.6$ & $1233 \pm 234$ & $1.556 \pm 0.045$ & $1.544 \pm 0.046$ & $81.3 \pm 6.4$ & $330 \pm 622$ \\
\hline
\end{tabular}


Table 2

Average \pm standard deviation of wind speed, air-water $\mathrm{pCO}_{2}$ gradient, atmospheric $\mathrm{CO}_{2}$ flux and the gas transfer velocity $k$, in the Kiên Vàng and Tam Giang mangrove creeks and adjacent main channels during the rainy and dry seasons

\begin{tabular}{lllcr}
\hline Sites & Season & $\begin{array}{l}\text { Wind speed } \\
\left(\mathrm{m} \mathrm{s}^{-1}\right)\end{array}$ & $\begin{array}{l}\Delta \mathrm{pCO}_{2} \\
(\mathrm{ppm})\end{array}$ & $\begin{array}{c}\text { Atmospheric } \mathrm{CO}_{2} \text { flux } \\
\left(\mathrm{mmol} \mathrm{C} \mathrm{m}^{-2} \mathrm{~d}^{-1}\right)\end{array}$ \\
\hline Kiên Vàng & Dry & $1.6 \pm 2.2$ & $1511 \pm 1196$ & $32.2 \pm 39.4$ \\
& Rainy & $3.0 \pm 2.3$ & $3286 \pm 1856$ & $154.7 \pm 159.1$ \\
Tam Giang & Dry & $2.4 \pm 1.3$ & $4457 \pm 4105$ & $141.5 \pm 117.8$ \\
& Rainy & $1.9 \pm 1.1$ & $4333 \pm 2187$ & $128.5 \pm 110.0$ \\
Adjacent main channels & Dry & $5.5 \pm 3.0$ & $353 \pm 144$ & $27.1 \pm 12.5$ \\
& Rainy & $5.3 \pm 0.9$ & $867 \pm 234$ & $81.3 \pm 31.8$ \\
\hline
\end{tabular}
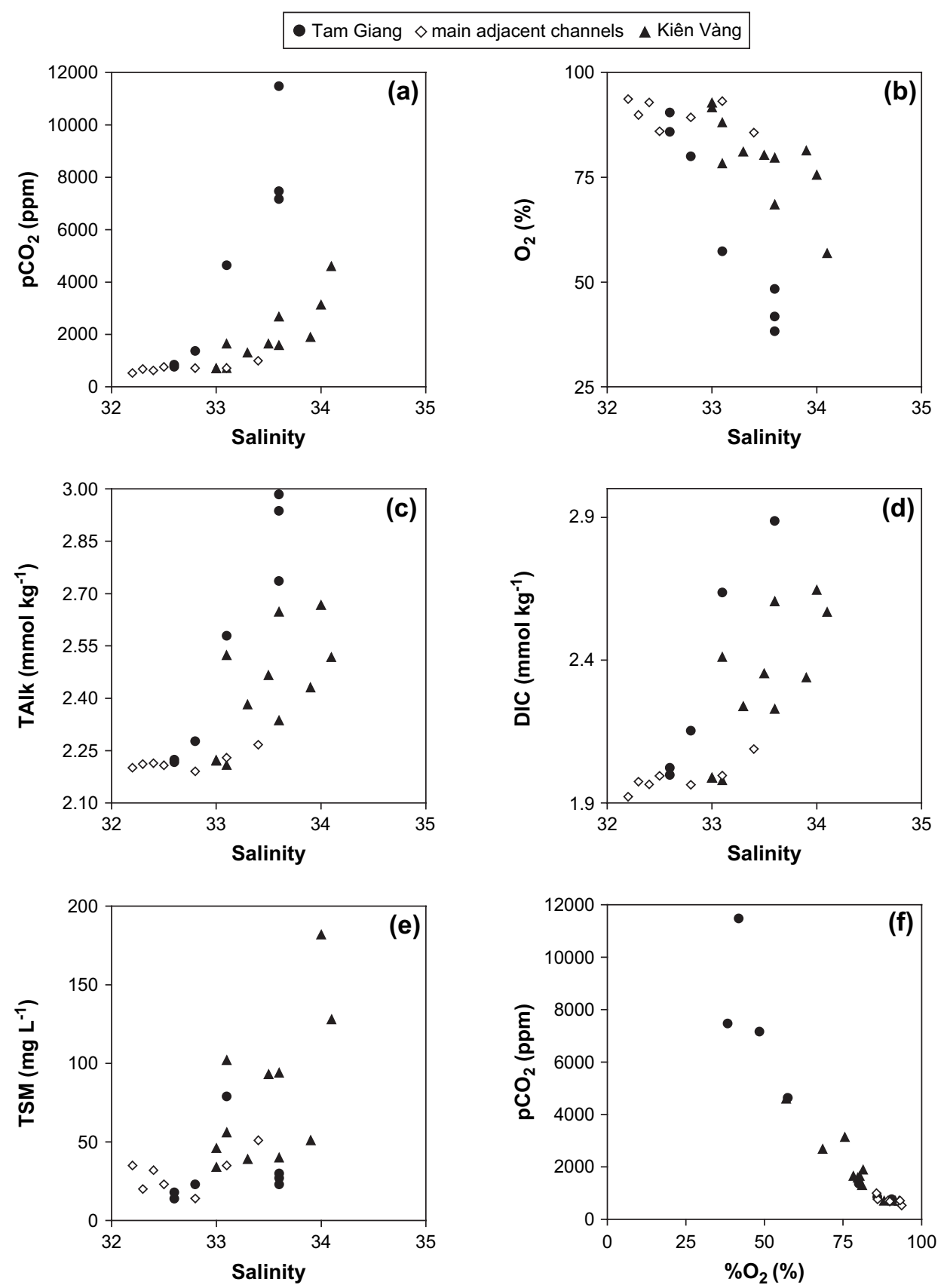

Fig. 6. Variation of $\mathrm{pCO}_{2}(\mathrm{ppm}), \% \mathrm{O}_{2}(\%)$, TAlk $\left(\mathrm{mmol} \mathrm{kg}^{-1}\right)$, DIC $\left(\mathrm{mmol} \mathrm{kg}^{-1}\right)$ and TSM $\left(\mathrm{mg} \mathrm{L}^{-1}\right)$ as a function of salinity in the mangrove creeks (Tan Giang, solid circles and Kiên Vàng, solid triangles) and adjacent main channels (open diamonds), and $\mathrm{pCO}_{2}$ versus $\% \mathrm{O}_{2}$ during the dry season. 

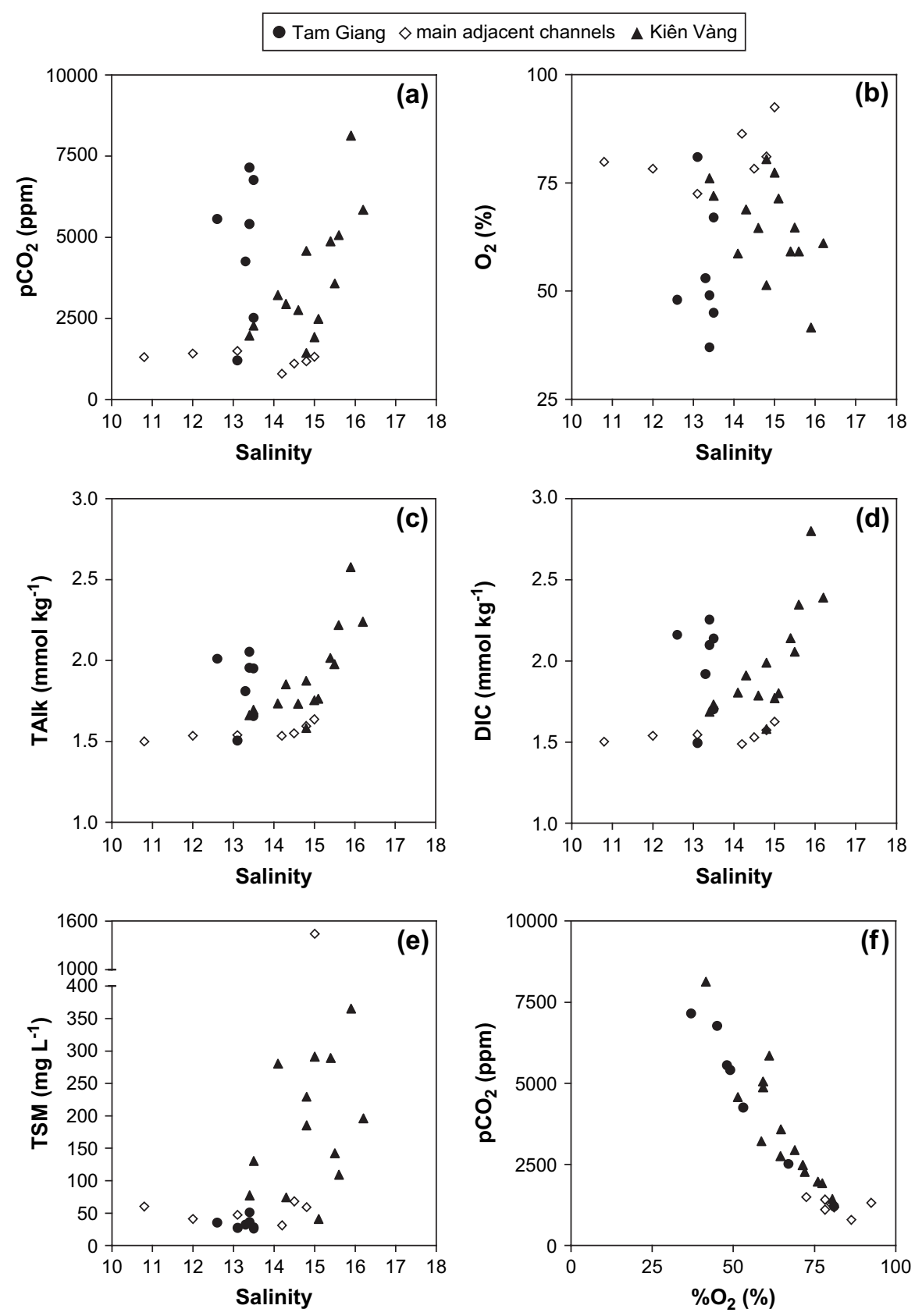

Fig. 7. Variation of $\mathrm{pCO}_{2}(\mathrm{ppm}), \% \mathrm{O}_{2}(\%)$, TAlk $\left(\mathrm{mmol} \mathrm{kg}^{-1}\right)$, DIC $\left(\mathrm{mmol} \mathrm{kg}^{-1}\right)$ and TSM $\left(\mathrm{mg} \mathrm{L}^{-1}\right)$ as a function of salinity in the mangrove creeks (Tan Giang, solid circles and Kiên Vàng, solid triangles) and adjacent main channels (open diamonds), and $\mathrm{pCO}_{2}$ versus $\% \mathrm{O}_{2}$ during the rainy season.

Alongi et al. (2000b), the magnitude of these processes depends of the dominant species of mangrove trees; these authors also reported that sulphate reduction rates were significantly correlated with live root biomass, aboveground biomass and forest net primary production. Denitrification is assumed to be a minor pathway for diagenetic organic carbon degradation and has only been observed in the oldest mangrove forests of the Mekong delta (Alongi et al., 2000a). Only in the Bangrong mangrove area (Thailand), iron reduction has been reported as the predominant diagenetic carbon degradation process (Kristensen et al., 2000), while in Matang mangrove forest (Malaysia), manganese reduction and denitrification-nitrification coupled with aerobic respiration, accounted for most organic matter degradation (Alongi et al., 1998). Finally, based on pore water chemistry in Gazi Bay (Kenya), Middelburg et al. (1996) suggested that the acidification of pore waters due to anaerobic diagenetic degradation processes led to the dissolution of calcium carbonates (also increasing TAlk).

Whatever the process that dominated diagenetic organic carbon degradation in Tam Giang and Kiên Vàng, the high TAlk and DIC values in the mangrove creeks were consistent with the enrichment of these quantities in the creek waters due to the influx of pore waters, during both seasons. The relative variation of TAlk normalised to a constant salinity (nTAlk) versus DIC normalised to a constant salinity (nDIC) is an indicator of the dominant biogeochemical process 
affecting directly or indirectly these quantities. TAlk and DIC were normalised to a constant salinity of 32 in order to minimise evaporation/dilution effects on these quantities. During the dry season, nTAlk and nDIC were well correlated in the Tam Giang mangrove creeks $\left(r^{2}=0.99\right.$ of the linear regression) and the Kiên Vàng mangrove creeks $\left(r^{2}=0.93\right.$ of the linear regression) with slopes of, respectively, 0.61 and 0.62 (Fig. 8). The values of the slopes were lower if sulphate reduction was the only biogeochemical process controlling these variables; this suggests that aerobic respiration and/or air-water exchange of $\mathrm{CO}_{2}$ also strongly contributed to the variation of DIC in the water column. During the rainy season, nTAlk and nDIC were also well correlated in the Tam Giang mangrove creeks $\left(r^{2}=0.99\right.$ of the linear regression) and the Kiên Vàng mangrove creeks $\left(r^{2}=0.99\right.$ of the linear regression) with slopes of, respectively, 0.74 and 0.78 (Fig. 8). This suggests that during the rainy season, the enrichment of DIC and TAlk in the creek waters was also partly due to the influx of pore waters. The slopes were also consistent with a strong contribution by sulphate reduction, despite the fact that a decrease of this diagenetic process would have been expected due to the lower availability by sulphate due to dilution during the rainy season. During both seasons, no correlation was found between nTAlk and nDIC in the main adjacent channels and the range of variations was much smaller than in the tidal creeks (data not shown). This suggests that pore water influx did not affect DIC and TAlk in the main adjacent channels since the water volume is more important, and probably the water residence time shorter than in the mangrove creeks.

\subsection{Air-water $\mathrm{CO}_{2}$ fluxes}

During the dry season, air-water $\mathrm{CO}_{2}$ fluxes ranged from $27.1 \mathrm{mmol} \mathrm{C} \mathrm{m}^{-2} \mathrm{~d}^{-1}$ to $141.5 \mathrm{mmol} \mathrm{C} \mathrm{m}^{-2} \mathrm{~d}^{-1}$, and the average air-water $\mathrm{CO}_{2}$ flux was significantly higher in the Tam Giang mangrove creeks than in the Kiên Vàng mangrove creeks and than in the adjacent main channels, in accordance with $\Delta \mathrm{pCO}_{2}$ values (Table 2). During the dry season, average air-water $\mathrm{CO}_{2}$ flux was not significantly different in the Kiên Vàng mangrove creeks and in the adjacent main channels. During the rainy season, the air-water $\mathrm{CO}_{2}$ fluxes ranged from $81.3 \mathrm{mmol} \mathrm{C} \mathrm{m}^{-2} \mathrm{~d}^{-1}$ to $154.7 \mathrm{mmol} \mathrm{C} \mathrm{m}^{-2} \mathrm{~d}^{-1}$, and the average air-water $\mathrm{CO}_{2}$ flux highly significantly increased 5 fold in the Kiên Vàng mangrove creeks, and very significantly increased 3 fold in the adjacent main channels compared to the dry season. This increase can be explained by the significantly to highly significantly higher average $\Delta \mathrm{pCO}_{2}$ values during the rainy season, for, respectively, the Kiên Vàng mangrove creeks and the adjacent main channels. Indeed, in the Kiên Vàng mangrove creeks and in the adjacent main channels, wind speed was not significantly different between the two seasons. In the Tam Giang mangrove creeks, the average air-water $\mathrm{CO}_{2}$ flux was not significantly different during both seasons in agreement with $\Delta \mathrm{pCO}_{2}$.
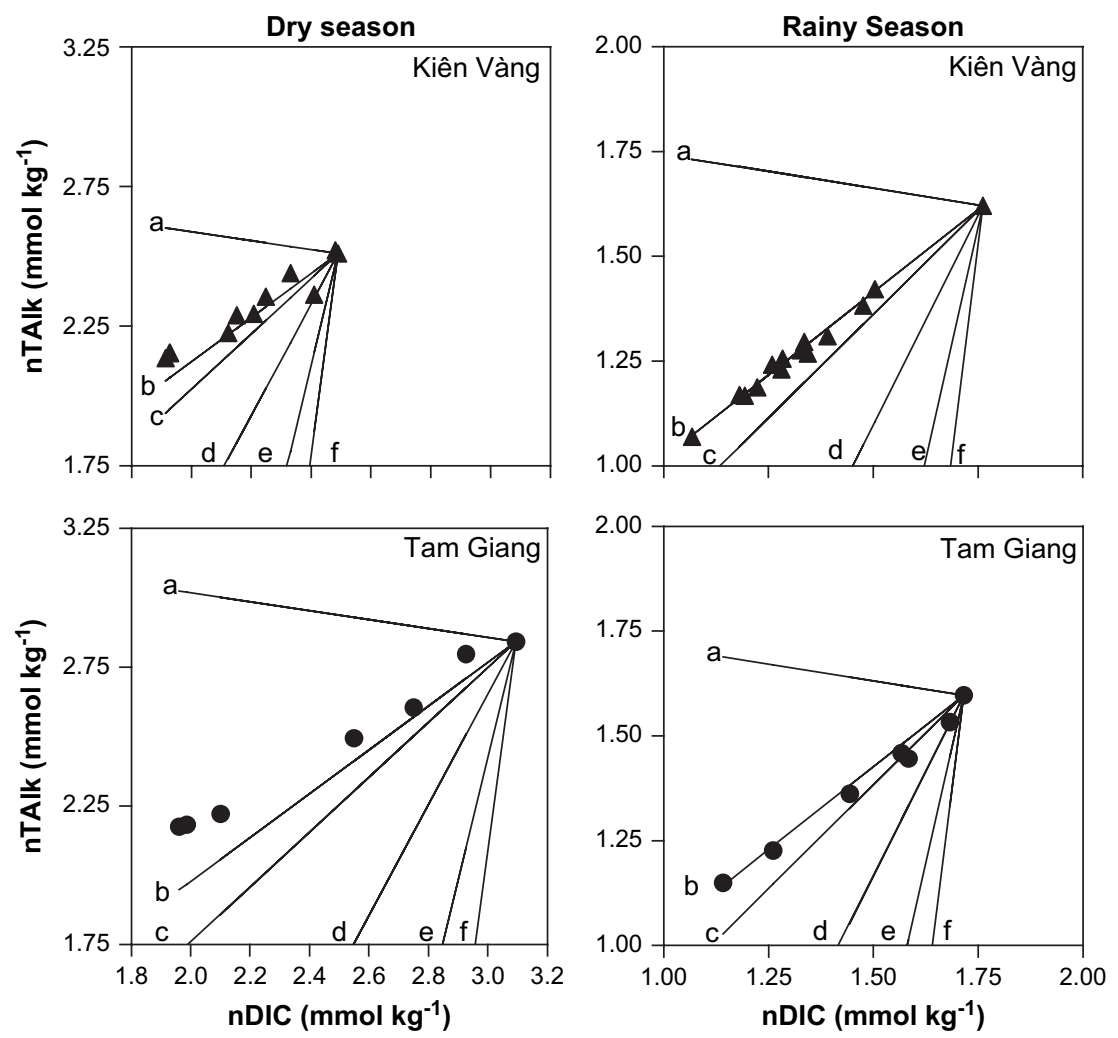

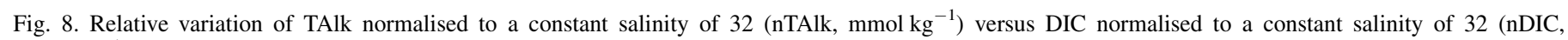

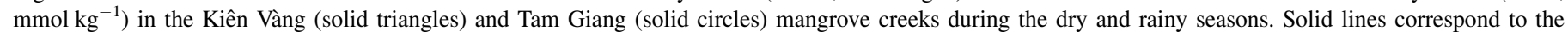

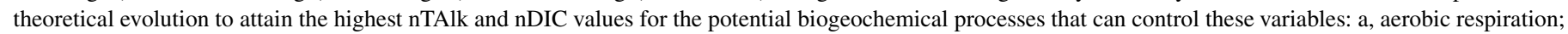
$\mathrm{b}$, denitrification; c, sulphate reduction; $\mathrm{d}, \mathrm{CaCO}_{3}$ dissolution; e, manganese reduction; f, iron reduction. 
Table 3

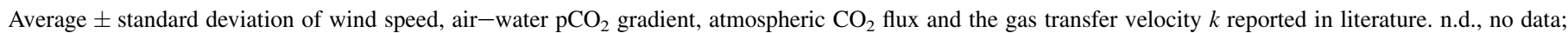
LM86 $=k$ parameterisation from Liss and Merlivat (1986)

\begin{tabular}{|c|c|c|c|c|c|}
\hline Sites & $\begin{array}{l}\text { Wind speed } \\
\left(\mathrm{m} \mathrm{s}^{-1}\right)\end{array}$ & $\begin{array}{l}\Delta \mathrm{pCO}_{2} \\
(\mathrm{ppm})\end{array}$ & $\begin{array}{l}\text { Atmospheric } \mathrm{CO}_{2} \text { flux } \\
\left(\mathrm{mmol} \mathrm{C} \mathrm{m}{ }^{-2} \mathrm{~d}^{-1}\right)\end{array}$ & $\begin{array}{l}k \\
\left(\mathrm{~cm} \mathrm{~h}^{-1}\right)\end{array}$ & References \\
\hline Nagada Creek (Papua New Guinea) & $3.0 \pm 2.1$ & $799 \pm 357$ & $43.6 \pm 33.2$ & $8 \pm 6$ & Borges et al. (2003) \\
\hline Norman's Pond (Bahamas) & $5.5 \pm 1.3$ & $165 \pm 86$ & $13.8 \pm 8.3$ & $13 \pm 3$ & Borges et al. (2003) \\
\hline Gaderu Creek (India) & $1.4 \pm 1.9$ & $2215 \pm 864$ & $56 \pm 100.9$ & $4 \pm 5$ & Borges et al. (2003) \\
\hline Saptamukhi Creek (India) & n.d. & $2210 \pm 1460$ & $56.7 \pm 37.4$ & 4 & Borges et al. (2003) based on Ghosh et al. (1987) \\
\hline Mooringanga Creek (India) & n.d. & $830 \pm 363$ & $23.2 \pm 10.1$ & 4 & Borges et al. (2003) based on Ghosh et al. (1987) \\
\hline Fringe of Sundarban forest (India) & n.d. & $110 \pm 321$ & 0.4 & LM86 & Biswas et al. (2004) \\
\hline Itacuraçá Creek (Brazil) & n.d. & $3845 \pm 3520$ & $113.5 \pm 104.4$ & 4 & Borges et al. (2003) based on Ovalle et al. (1990) \\
\hline Florida Bay (USA) & n.d. & $170 \pm 200$ & $4.6 \pm 5.4$ & 4 & Borges et al. (2003) based on Millero et al. (2001) \\
\hline Shark River (USA) & n.d. & $1285 \pm 1485$ & $43.8 \pm 52.1$ & 4 & $\begin{array}{l}\text { Based on data available at } \\
\text { http://www.rsmas.miami.edu/groups/jmc/fla-bay/fbay.html }\end{array}$ \\
\hline
\end{tabular}

Although during the dry season the average $\Delta \mathrm{pCO}_{2}$ was significantly 5 times lower in the adjacent main channels than in the Kiên Vàng mangrove creeks, the average air-water $\mathrm{CO}_{2}$ flux was not significantly different, due to the very significantly higher wind speeds and $k$ values in the adjacent main channels. This was due to the presence of trees and the narrowness of the tidal creeks that reduced the air-water $\mathrm{CO}_{2}$ fluxes by limiting wind speed. This is in agreement with a recent analysis of airwater $\mathrm{CO}_{2}$ fluxes in Gazi bay that shows a very large contribution of open waters compared to mangrove creek waters to the overall emission of $\mathrm{CO}_{2}$ from the whole mangrove aquatic system (Bouillon et al., 2007c). The average $k$ value in the Kiên Vàng and Tam Giang mangrove creeks ranged from $3 \mathrm{~cm} \mathrm{~h}^{-1}$ to $5 \mathrm{~cm} \mathrm{~h}^{-1}$ and from $4 \mathrm{~cm} \mathrm{~h}^{-1}$ to $6 \mathrm{~cm} \mathrm{~h}^{-1}$ during, respectively, the dry and rainy seasons. This confirms that the use of a constant $k$ value of $4 \mathrm{~cm} \mathrm{~h}^{-1}$ is adequate for sheltered mangrove creeks (Borges et al., 2003).

Our results are within the range of air-water $\mathrm{CO}_{2}$ fluxes in aquatics systems associated to other mangrove forests (Table 3 ). The representativeness of the Millero et al. (2001) data for Florida's mangrove creeks is not straightforward, since they were obtained in the open waters of Florida Bay and some of the sampling stations were located about $30 \mathrm{~km}$ from the mangrove fringe. The data from Shark River are most probably more representative of the Florida Bay mangrove creeks than the values within the bay itself reported by Millero et al. (2001). Indeed, Ovalle et al. (1999) concluded that mangrove forests did not affect the chemistry of the shelf waters of Eastern Brazil, even at stations located $2 \mathrm{~km}$ away from the mangrove fringe. Similarly, Biswas et al. (2004) recently reported an annually integrated air-water $\mathrm{CO}_{2}$ flux of $0.4 \mathrm{mmol} \mathrm{C} \mathrm{m}^{-2} \mathrm{~d}^{-1}$ at the fringe of the Sundarban mangrove forest that was much lower than the values in two creeks (Mooringanga and Saptamukhi) within the mangrove forest. This suggests that the export of DIC from mangroves does not seem to affect the air-water $\mathrm{CO}_{2}$ fluxes in the adjacent aquatic ecosystems where the DIC is rapidly "diluted".

The air-water $\mathrm{CO}_{2}$ fluxes computed for the Ca Mau mangrove creeks are consistent with previous estimates in mangrove surrounding waters (Table 3) and confirm that an overall value of $50 \mathrm{mmol} \mathrm{C} \mathrm{m}^{-2} \mathrm{~d}^{-1}$ given by Borges et al. (2003) was a reasonable first order general estimate. Based on data from Tables 2 and 3, we can re-evaluate the air-water $\mathrm{CO}_{2}$ emission from mangroves to $72 \mathrm{mmol} \mathrm{C} \mathrm{m}{ }^{-2} \mathrm{~d}^{-1}$ that upward scaled to the most recent surface area of mangrove forests $\left(146 \times 10^{3} \mathrm{~km}^{2}\right.$ in $\left.2000 ; \mathrm{FAO}, 2003\right)$ provides a $\mathrm{CO}_{2}$ emission

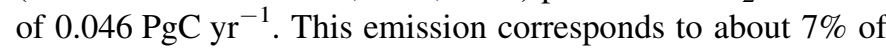
the overall emission from open oceanic waters at sub-tropical and tropical latitudes $\left(30^{\circ} \mathrm{N}-30^{\circ} \mathrm{S}, 0.71 \mathrm{PgC} \mathrm{yr}^{-1}\right.$, based on Takahashi et al. (2002)) and to $24 \%$ of the overall emission of about $0.19 \mathrm{PgC} \mathrm{yr}^{-1}$ from coastal waters (including estuaries, marginal seas, coastal upwelling systems and coral reefs) at the same latitudes based on the compilation by Borges et al. (2005).

\section{Acknowledgements}

The authors are indebted to the Research Institute for Aquaculture no. 2 (Ho Chi Minh City) for help in setting up the cruises and logistical support in the field. This work was funded by the Fonds National de la Recherche Scientifique (contract no. 1.5.066.03), where A.V.B. is a research associate. Y.J.-M.K. received financial support from the Ivory Coast government and from the Agence Universitaire de la Francophonie (6313PS657). Two anonymous reviewers provided constructive comments on a previous version of the paper. B. Delille and N. Gypens helped with statistical analysis. This is MARE contribution 114.

\section{References}

Alongi, D.M., 1998. Coastal Ecosystem Processes. CRC Press, Boca Raton, $419 \mathrm{pp}$.

Alongi, D.M., Sasekumar, A., Tirendi, F., Dixon, P., 1998. The influence of stage age on benthic decomposition and recycling of organic matter in managed mangrove forests of Malaysia. Journal of experimental Marine Biology and Ecology 225, 197-218.

Alongi, D.M., Tirendi, F., Trott, L.A., Xuan, T.T., 2000a. Benthic decomposition rates and pathways in plantations of mangrove Rhizophora apiculata in Mekong delta. Vietnam. Marine Ecology Progress Series 194, 87-101.

Alongi, D.M., Tirendi, F., Clough, B.F., 2000b. Below ground decomposition of organic matter in forests of the mangroves Rhizophora stylosa and Avicennia marina along the arid coast of Western Australia. Aquatic Botany 68, 97-122.

Alongi, D.M., Wattayakorn, G., Pfitzner, J., Tirendi, F., Zagorskis, I., Brunskill, G.J., Davidson, A., Clough, B.F., 2001. Organic carbon 
accumulation and metabolic pathways in sediments of mangrove forests in southern Thailand. Marine Geology 179, 85-103.

Barnes, J., Ramesh, R., Purvaja, R., Nirmal Rajkumar, A., Senthil Kumar, B., Krithika, K., Ravichandran, K., Uher, G., Upstill-Goddard, R., 2006. Tidal dynamics and rainfall control $\mathrm{N}_{2} \mathrm{O}$ and $\mathrm{CH}_{4}$ emissions from a pristine mangrove creek. Geophysical Research Letters 33, L15405. doi:10.1029/ 2006GL026829.

Binh, C.T., Phillips, M.J., Demaine, H., 1997. Integrated shrimp-mangrove farming systems in the Mekong delta of Vietnam. Aquaculture Research 28, 599-610.

Biswas, H., Mukhopadhyay, S.K., De, T.K., Sen, S., Jana, T.K., 2004. Biogenic controls on the air-water carbon dioxide exchange in the Sundarban mangrove environment, northeast coast of Bay of Bengal, India. Limnology and Oceanography 49, 95-101.

Borges, A.V., 2005. Do we have enough pieces of the jigsaw to integrate $\mathrm{CO}_{2}$ fluxes in the Coastal Ocean? Estuaries 28 (1), 3-27.

Borges, A.V., Djenidi, S., Lacroix, G., Théate, J., Delille, B., Frankignoulle, M., 2003. Atmospheric $\mathrm{CO}_{2}$ flux from mangrove surrounding waters. Geophysical Research Letters 30, 11-14.

Borges, A.V., Delille, B., Frankignoulle, M., 2005. Budgeting sinks and sources of $\mathrm{CO}_{2}$ in the coastal ocean: diversity of ecosystems counts. Geophysical Research Letters 32, L14601. doi:10.1029/2005GL023053.

Borges, A.V., Schiettecatte, L.-S., Abril, G., Delille, B., Gazeau, F., 2006. Carbon dioxide in European coastal waters. Estuarine, Coastal and Shelf Science 70 (3), 375-387.

Bouillon, S., Boschker, H.T.S., 2006. Bacterial carbon sources in coastal sediments: a cross-system analysis based on stable isotope data of biomarkers. Biogeosciences 3, 175-185.

Bouillon, S., Frankignoulle, M., Dehairs, F., Velimirov, B., Eiler, A., Abril, G., Etcheber, H., Borges, A.V., 2003. Inorganic and organic carbon biogeochemistry in the Gautami Godavari esturay (Andhra Pradesh, India) during pre-monsoon: The local impact of extensive mangrove forest. Global Biogeochemistry Cycles 17, 1114.

Bouillon, S., Moens, T., Koedam, N., Dahdouh-Guebas, F., Baeyens, W., Dehairs, F., 2004. Variability in the origin of carbon substrates for bacterial communities in mangrove sediments. FEMS Microbiology Ecology 49, $171-179$

Bouillon, S., Dehairs, F., Schiettecatte, L.-S., Borges, A.V., 2007a. Biogeochemistry of the Tana estuary and delta (northern Kenya). Limnology and Oceanography 52 (1), 45-59.

Bouillon, S., Middelburg, J.J., Dehairs, F., Borges, A.V., Abril, G., Flindt, M.R., Ulomi, S., Kristensen, E., 2007b. Importance of intertidal sediment processes and porewater exchange on the water column biogeochemistry in a pristine mangrove creek (Ras Dege, Tanzania). Biogeosciences 4, 311-322.

Bouillon, S., Dehairs, F., Velimirov, B., Abril, G., Borges, A.V., 2007c. Dynamics of organic and inorganic carbon across contiguous mangrove and seagrass systems (Gazi bay, Kenya). Journal of Geophysical ResearchBiogeosciences 112, G02018. doi:10.1029/2006JG000325.

Carini, S., Weston, N., Hopkinson, C., Tucker, J., Giblin, A., Vallino, J., 1996. Gas exchange rates in the Parker River estuary. Massachusetts. Biological Bulletin 191, 333-334.

Clough, B., Johnston, D., Xuan, T.T., Phillips, M.J., Pednekar, S.S., Thien, N.H., Dan, T.H., Thong, P.L., 2002. Silvofishery Farming Systems in Ca Mau Province. Report prepared under the World Bank. NACA, WWF and FAO Consortium Program on Shrimp Farming and the Environment, Vietnam, 70 pp.

Cole, J.J., Caraco, N.F., 2001. Carbon in catchments: connecting terrestrial carbon losses with aquatic metabolism. Marine and Freshwater Research 52 (1), 101-110.

Duarte, C.M., Prairie, Y.T., 2005. Prevalence of heterotrophy and atmospheric $\mathrm{CO}_{2}$ emissions from aquatic ecosystems. Ecosystems 8, 862-870.

Duarte, C.M., Middelburg, J.J., Caraco, N., 2005. Major role of marine vegetation on oceanic carbon cycle. Biogeosciences 2, 1-8.
FAO, 2003. State of the World's Forests (SOFO). Food and Agriculture Organization of the United Nations, Rome, $100 \mathrm{pp}$.

Frankignoulle, M., Borges, A.V., 2001a. European continental shelf as a significant sink for atmospheric carbon dioxide. Global Biogeochemical Cycles $15,569-576$.

Frankignoulle, M., Borges, A.V., 2001b. Direct and indirect $\mathrm{pCO}_{2}$ measurements in a wide range of $\mathrm{pCO}_{2}$ and salinity values (the Scheldt estuary). Aquatic Geochemistry 7, 267-273.

Gattuso, J.-P., Frankignoulle, M., Wollast, R., 1998. Carbon and carbonate metabolism in coastal aquatic ecosystems. Annual Review Ecology Systematics 29, 405-434.

Ghosh, S., Jana, T.K., Singh, B.N., Choudhury, A., 1987. Comparative study of carbon dioxide system in virgin and reclaimed mangrove waters of Sundarbans during freshet. Mahasagar: Bulletin of the National Institute of Oceanography $20,155-161$.

Holmer, M., Andersen, F.Ø., Holmboe, N., Kristensen, E., Thongtham, N., 2001. Spatial and temporal variability in benthic processes along mangrove-seagrass transect near the Bangrong mangrove, Thailand. Wetlands Ecology and Management 9, 141-158.

Jennerjahn, T.C., Ittekkot, V., 2002. Relevance of mangroves for production and deposition of organic matter along tropical margins. Naturwissenschaften $89,23-30$.

Jones Jr., J.B., Mulholland, P.J., 1998. Carbon dioxide variation in a hardwood forest stream: an integrative measure of whole catchment soil respiration. Ecosystems 1, 183-196.

Jones Jr., J.B., Stanley, E.H., Mulholland, P.J., 2003. Long-term decline in carbon dioxide supersaturation in rivers across the contiguous United States. Geophysical Research Letters 30 (10), 1495. doi:10.1029/2003GL017056.

Kling, G.W., Kipphut, G.W., Miller, M.C., 1991. Arctic lakes and streams as gas conduits to the atmosphere: implications for tundra carbon budgets. Science 251, 298-301.

Kristensen, E., Andersen, F.Ø., Holmboe, N., Holmer, M., Thongtham, N., 2000. Carbon and nitrogen mineralization in sediments of the Bangrong mangrove area, Phuket, Thailand. Aquatic Microbial Ecology 22, 199-213.

Liss, P., Merlivat, L., 1986. Air-sea exchange rates: introduction and synthesis. In: Buat-Ménard, P. (Ed.), The Role of Air-Sea Exchange in Geochemical Cycling. Reidel, pp. 113-127.

Ludwig, W., Probst, J.L., Kempe, S., 1996. Predicting the oceanic input of organic carbon by continental erosion. Global Biogeochemical Cycles 10, $23-41$.

Middelburg, J.J., Nieuwenhuize, J., Slim, F.J., Ohawa, B., 1996. Sediment biogeochemistry in an East African mangrove forest (Gazi Bay, Kenya). Biogeochemistry 34, 133-155.

Millero, F.J., Hiscock, W.T., Huang, F., Roche, M., Zhang, J.Z., 2001. Seasonal variation of the carbonate system in Florida Bay. Bulletin of Marine Science 68, 101-123.

Ovalle, A.R.C., Rezende, C.E., Lacerda, L.D., Silva, C.A.R., 1990. Factors affecting the hydrochemistry of a mangrove tidal creek. Sepetiba bay, Brazil. Estuarine, Coastal and Shelf Science 31, 639-650.

Ovalle, A.R.C., Rezende, C.E., Carvalho, C.E.V., Jennerjahn, T.C., Ittekkot, V., 1999. Biogeochemical characteristics of coastal waters adjacent to small river-mangrove systems, East Brazil. Geo-Marine Letters 19, 179-185.

Takahashi, T., Sutherland, S.C., Sweeney, C., Poisson, A., Metzl, N., Tilbrook, B., Bates, N.R., Wanninkhof, R., Feely, R.A., Sabine, C., Olafsson, J., Nojiri, Y., 2002. Global sea-air $\mathrm{CO}_{2}$ flux based on climatological surface ocean $\mathrm{pCO}_{2}$, and seasonal biological and temperature effects. Deep-Sea Research Part II 49, 1601-1622.

Thomas, H., Bozec, Y., Elkalay, K., De Baar, H.J.W., 2004. Enhanced open ocean storage of $\mathrm{CO}_{2}$ from shelf sea pumping. Science 304, 1005-1008.

Thornton, C., Shanahan, M., Williams, J., 2003. From wetlands to wastelands: impacts of shrimp farming. The Society of Wetland Scientists Bulletin 20, $48-53$.

Tsunogai, S., Watanabe, S., Sato, T., 1999. Is there a "continental shelf pump" for the absorption of atmospheric $\mathrm{CO}_{2}$ ? Tellus Series B 5, 701-712. 